\title{
LEgislative STRATEgIES FOR ENCOURAGING ORgAN Donation: Providing Protection and Incentives TO LIVING ORGAN DONORS
}

\author{
ANNIE HILLS ${ }^{*}$
}

\section{INTRODUCTION}

An organ isn't the only thing you will lose if you become a living organ donor. A recent study found that more than a third of living kidney donors reported lost wages in the first year following donation. ${ }^{1}$ Tim Nagel of Wisconsin experienced this difficulty first hand after donating a kidney to his sister in $2014 .^{2}$ After being unable to work during his nine weeks of recovery time, Nagel faced $\$ 6,000$ in lost wages and was prepared to sell his tractor, snowmobile, and guns to make up for the deficit. ${ }^{3}$ Although Nagel eventually recovered his lost wages through a fundraiser put on by his friends and family, the Wisconsin resident believes the government "should make it easier for people to donate."4

Several states have enacted laws that provide rights and protections to living organ donors; however, no consistent national policy currently exists for these individuals. ${ }^{5}$ Meanwhile, the number of people on the organ waiting list continues to exceed the number of donors and transplants. ${ }^{6}$ The Sydney School of Public Health examined this widening gap and found that several barriers and concerns deter potential living donors, including fears about surgical and health risks, lack of knowledge about organ donation, and financial loss. ${ }^{7}$ The organ shortage crisis

* J.D. Candidate, 2020, Indiana University Robert H. McKinney School of Law.

1. Lauran Neergaard, Doctors Explore Lifting Barriers to Living Organ Donation, CHI. TRIB. (Sept. 10, 2018), https://www.chicagotribune.com/lifestyles/health/ct-living-organ-donation20180910-story.html [https://perma.cc/XFV7-L9EX].

2. David Wahlberg, Efforts Aim to Reimburse or Pay Living Organ Donors, Wis. ST. J. (Sept. 14, 2015), https://madison.com/wsj/news/local/health-med-fit/efforts-aim-to-reimburse-orpay-living-organ-donors/article_c $34 \mathrm{f} 3 \mathrm{cfb}-097 \mathrm{~b}-5228-89 \mathrm{~cd}-7 \mathrm{f} 1 \mathrm{c} 8 \mathrm{ec} 00220 . \mathrm{html}$ [perma.cc/8AP8563K].

3. Id.

4. Id.

5. American Kidney Fund, Great News for Living Organ Donors: U.S. Department of Labor Says Organ Donors are Protected Under FMLA, GlobeNewswiRe (Aug. 29, 2018), https://globenewswire.com/news-release/2018/08/29/1558470/0/en/Great-News-for-Living-OrganDonors-U-S-Department-of-Labor-Says-Organ-Donors-are-Protected-Under-FMLA.html [perma.cc/LCV4-GDFK].

6. Organ Donation Statistics, U.S. Dep't of Health and Hum. Serv. https://www. organdonor.gov/statistics-stories/statistics.html (last visited Nov. 29, 2018) [perma.cc/9N9DS54N].

7. Allison Tong et al., Public Awareness and Attitudes to Living Organ Donation: Systematic Review and Integrative Synthesis, TRANSPLANTATION (Sept. 15, 2013), https://journals. lww.com/transplantjournal/fulltext/2013/09150/Public_Awareness_and_Attitudes_to_Living_O rgan.3.aspx [perma.cc/XWQ9-94DR]. 
has not gone unnoticed by members of Congress. ${ }^{8}$ Both Democratic and Republican Representatives have proposed legislation to try and increase the number of living donors in the United States; however, these efforts have been unsuccessful. ${ }^{9}$

The first piece of proposed legislation is the Living Donor Protection Act. ${ }^{10}$ U.S. Representatives Jerrold Nadler and Jaime Herrera Beutler introduced the Living Donor Protection Act ("LDPA") to protect the rights of living organ donors. ${ }^{11}$ The LDPA is a response to the growing disparity between the number of patients in need of transplantation and the availability of transplantable organs. ${ }^{12}$ The LDPA aims to protect living organ donors and promote organ donation in three easy and economical ways. ${ }^{13}$ First, the LDPA prohibits insurance companies from denying coverage or increasing premiums of life or disability insurance for living organ donors. ${ }^{14}$ Second, the LDPA clarifies that organ donation surgery qualifies as a serious health condition under the Family Medical Leave Act ("FMLA"). ${ }^{15}$ Third, it requires the Secretary of Health and Human Services ("HHS") to update education materials on the benefits of organ donation. ${ }^{16}$ Nadler and Beutler introduced the LDPA to Congress in 2014, 2016, 2017, and 2019. ${ }^{17}$

With a similar motive as was behind the Living Donor Protection Act, U.S. Representative Matt Cartwright introduced the Organ Donor Clarification Act ("ODCA"). ${ }^{18}$ Cartwright's proposed legislation intends to remove existing barriers that organ donors face under current law and to provide incentives to potential donors in hopes of encouraging more Americans to consider donating. ${ }^{19}$ The buying and selling of organs is illegal under the National Organ Transplant Act of 1984 ("NOTA"), but Cartwright's legislation seeks to clarify that certain types of payments and/or reimbursements relating to organ donation would not

8. See Living Donor Protection Act of 2017, H.R. 1270, 115th Cong. § 2 (2017); Organ Donation Clarification Act of 2018, H.R. 6448, 115th Cong. (2018).

9. Id.

10. Living Donor Protection Act of 2019, H.R. 1224, 116th Cong. (2019).

11. Living Donor Protection Act Introduced, AM. SoC'Y OF TRANSPLANT SurgeOns (Mar. 1, 2017), https://asts.org/news-and-publications/asts-news/article/2017/03/01/living-donorprotection-act-introduced\#.W5sIsS3Mw_U [perma.cc/P8XQ-8RCX].

12. Lara C. Pullen, Cautious Optimism for Transplantation Under Trump Administration, AJT REP. (Jan. 25, 2017), https://onlinelibrary.wiley.com/doi/full/10.1111/ajt.14177 [perma.cc/ RL68-3UT5].

13. Living Donor Protection Act Introduced, supra note 11.

14. Living Donor Protection Act of 2017, H.R. 1270, 115th Cong. § 2 (2017)

15. Id.

16. Id.

17. Id.; Living Donor Protection Act of 2014, H.R. 5263, 113th Cong. (2014); Living Donor Protection Act of 2016, H.R. 4616, 114th Cong. (2016).

18. Organ Donation Clarification Act of 2018, H.R. 6448, 115th Cong. (2018).

19. Id. 
violate NOTA. ${ }^{20}$ Additionally, the ODCA would allow government-run pilot programs to test the effectiveness of providing noncash incentives to promote organ donation. ${ }^{21}$ Cartwright proposed the legislation in 2016 and 2018, but the bill has never passed committee. ${ }^{22}$

This Note argues that Congress should enact the LDPA and the ODCA to protect living organ donors, encourage more organ donation, and ultimately help end the organ shortage crisis in America. Part I of this Note sets forth the growing need for living organ donors and the current availability of organs in the United States. Additionally, this section compares an organ donation from a living donor to one from a deceased donor. Part II examines the current barriers that discourage living organ donation, including financial loss, insurance discrimination, and public misperceptions about the donation process. Part III of this Note discusses the various state laws protecting living organ donors and the need for a consistent federal policy. Part IV introduces the LDPA and the ODCA. Part $\mathrm{V}$ of this note discusses the criticisms of the proposed legislation and possible reasons for failure. Finally, Part VI argues that in order to narrow the widening gap between the need and the supply of organs, Congress needs to enact the LDPA and the ODCA to provide protection to living organ donors and test incentives to encourage donation. Further, this section argues that states should continue implementing new laws that protect and incentivize organ donors.

\section{THE NEED FOR LIVING ORGAN DONORS}

\section{A. America's Current Organ Shortage}

The current organ supply in the United States is a growing public concern. ${ }^{23}$ Although surgeons performed a record high of 36,530 transplants, roughly 114,000 Americans still remained on the transplant waiting list at the beginning of 2019. ${ }^{24}$ The unavailability of adequate organs for transplantation to meet the current demand has created a major organ shortage crisis in the United States. ${ }^{25}$ The wait time for an organ has lengthened over the years, and roughly twelve percent of people on the waiting list will die before getting a transplant. ${ }^{26}$ The

20. Id.

21. Id.

22. Id.; Organ Donation Clarification Act of 2016, H.R. 5344, 114th Cong. (2016).

23. See, e.g., G.M. Abouna, Organ Shortage Crisis: Problems and Possible Solutions, NCBI (Jan. 2008), https://www.ncbi.nlm.nih.gov/pubmed/18261540 [perma.cc/4HGZ-4Q35]; Rachel Mabe, Living Organ Donations Save Lives. Why Are They So Rare in America?, WaSH. MonTHLY (Sept. 5, 2018), https://washingtonmonthly.com/2018/09/05/living-organ-donations-save-lives-whyare-they-so-rare-in-america/ [https://perma.cc/L54A-BMXY].

24. Organ Procurement and Transplantation Network Data, U.S. DeP't of HeAlth \& Hum. SERV., https://optn.transplant.hrsa.gov/data/ (last visited Feb. 11, 2019) [perma.cc/WF99-EE76].

25. Abouna, supra note 23.

26. Mabe, supra note 23. 
Organ Procurement and Transplant Network identifies two donor types: living donors and deceased donors. ${ }^{27}$ Deceased donors are those who have chosen to donate their organs after death and make up a majority of all organ donations. ${ }^{28}$ The process of becoming a deceased organ donor is simple and can be done when you renew your driver's license or by signing a Uniform Donor Card. ${ }^{29}$ Still, the supply of deceased donor organs in the United States does not meet the demand, as over 12,000 candidates on the transplant waiting list died or became too sick to operate in 2018 due to the shortage. ${ }^{30}$

Consequently, "the deceased donor-organ shortage has driven the widespread adoption of living donor transplantation." ${ }^{31}$ Living donation occurs when a person chooses to donate an organ during his or her lifetime. ${ }^{32}$ Organs that can be donated while a person is alive include the kidney, liver, part of the lung, part of the pancreas, and part of the intestines. ${ }^{33}$ The most common living donations involve the kidney or liver, and ninety-five percent of the candidates currently awaiting a transplant are in need of one of these two organs. ${ }^{34}$ These organs are most commonly and safely donated by a living donor because an individual only needs one kidney to survive, and the liver can re-grow if part of it is removed.35 The total number of candidates on the waitlist for a kidney transplant has doubled since the year 2000, and approximately 4,000 people died on the 95,000-person kidney transplant waiting list in $2018 .{ }^{36}$ Living donors contributed to only seventeen percent of all transplant surgeries performed in the United States in 2016 and 2017, the lowest contribution in over two decades. ${ }^{37}$ Living donors provided approximately thirty-nine percent of the kidneys used in transplants in 2018 and only four percent used in liver transplants performed in $2018 .{ }^{38}$ As the number of candidates added to the waiting list continues to increase each year, ${ }^{39}$ the need for living organ donors progresses.

Living donors are often related to the organ recipient. ${ }^{40}$ Fifty-three percent of

27. Organ Procurement and Transplantation Network Data, supra note 24.

28. $I d$.

29. Be An Organ Donor, NAT'L KidNEY Found. OF LA., http://kidneyla.org/be-an-organdonor/ (last visited Feb. 11, 2019) [perma.cc/9THG-UVW4].

30. Organ Procurement and Transplantation Network Data, supra note 24.

31. Tong et al., supra note 7.

32. The Living Donation Process, U.S. Dep't of Health And Hum. SerV., https://www. organdonor.gov/about/process/living-donation.html (last visited Feb. 11, 2019) [https://perma.cc/ MJB9-UR9R].

33. Id.

34. Organ Procurement and Transplantation Network Data, supra note 24.

35. Organ Donation: Pass it On, News In Health (Mar. 2011), https://newsinhealth. nih.gov/2011/03/organ-donation-pass-it [perma.cc/UG8M-PJPE].

36. Organ Procurement and Transplantation Network Data, supra note 24.

37. $I d$.

38. Id.

39. Id.

40. Living Donation, BC TRANSPLANT, http://www.transplant.bc.ca/Pages/Living- 
living donations in 2018 were from siblings, parents, spouses, children, or other relatives. ${ }^{41}$ Living donors can also be unrelated to the recipient, such as a close friend, co-worker, or member of the community. ${ }^{42}$ A person may even choose to donate their organs to an unrelated stranger. Anonymous donation is rarer and only accounted for four percent of living organ donations in $2018 .{ }^{43}$ When a person chooses to become a living organ donor, the transplant center evaluates the individual to determine whether they are suitable to be a donor. ${ }^{44}$ The evaluation is to ensure that the potential donor is in good health and does not have any medical issues such as diabetes, cancer, high blood pressure, or other disease that would affect donation. ${ }^{45}$ Additionally, the evaluation assesses the potential donor's physical, psychological, and emotional health. ${ }^{46}$

\section{B. Living Organs Versus Deceased Organs}

In addition to the growing number of Americans in need of an organ transplant, an organ from a deceased donor may not suffice. ${ }^{47}$ The American Transplant Foundation reports that transplant candidates generally have better results when they receive organs from living donors compared to organs received from deceased donors. ${ }^{48}$ For example, receiving an organ from a living donor lessens the risk of rejection during the transplant. ${ }^{49}$ A living organ donor is the only chance of survival for twenty-nine-year-old Timothy Waites from South Carolina ${ }^{50}$ Waites is currently on the search for a living organ donor after two failed kidney transplants from deceased donors. ${ }^{51}$ Experts believe his best chance with transplant success is from a living donor. ${ }^{52}$ In addition to the lessened risk of rejection, a living organ typically has greater longevity than one from a deceased donor and usually functions immediately in the recipient. ${ }^{53}$

Donation.aspx (last visited Feb. 11, 2019) [perma.cc/XLLY6-XJYD].

41. Organ Procurement and Transplantation Network Data, supra note 24.

42. Living Donation, supra note 40.

43. Organ Procurement and Transplantation Network Data, supra note 24.

44. The Living Donation Process, supra note 32.

45. Id.

46. Id.

47. See Benefits and Risks of Becoming A Living Organ Donor, AM. TRANSPlant Found., https://www.americantransplantfoundation.org/about-transplant/living-donation/about-livingdonation/ (last visited Nov. 29, 2018) [perma.cc/L6T2-TSVV].

48. Id.

49. Id.

50. Megan Rivers, Lowcountry Man in Search of Living Organ Donor, ABC News 4 (Oct. 31, 2018), https://abcnews4.com/news/local/lowcountry-man-in-search-of-living-organ-donor [perma.cc/SEK2-9LXJ].

51. Id.

52. $I d$.

53. Benefits and Risks of Becoming A Living Organ Donor, supra note 47. 
Several factors make living donor organs less prone to rejection and more likely to last than a deceased donor organ. ${ }^{54}$ First, living donor organs are generally healthier. ${ }^{55}$ In order to become a living kidney donor, an individual is evaluated based on his or her kidney function, compatibility, and overall physical and mental health. ${ }^{56}$ Second, a kidney from a deceased donor may be stressed from spending a prolonged time outside of the human body, which can temporarily reduce organ function. ${ }^{57}$ Transplant surgeons consider living donor organs to be of better quality than deceased donor organs.$^{58}$ On average, the life span of a transplanted kidney from a deceased donor is three years shorter than a transplanted kidney from a living donor. ${ }^{59}$ From 2008 to 2015, the survival rate for a liver recipient five years after surgery was 83.9 percent when the liver came from a living donor, and only 75 percent when it came from a deceased donor. ${ }^{60}$

\section{BARRIERS TO LIVING ORGAN DONATION}

Despite the overwhelming support for organ donation and the growing need for living organ donors in the United States, few people decide to donate during their lifetime. ${ }^{61}$ When deciding whether to become a living organ donor, Americans often find the risk greater than the reward.$^{62}$ Living organ donors often face financial loss due to delays in returning to work and difficulties maintaining life, disability, and medical insurance coverage at the same level and rate. ${ }^{63}$ In addition to financial loss and insurance discrimination, many individuals are deterred from donating due to the fear of surgical and health risks and lack of knowledge about organ donation. ${ }^{64}$ Furthermore, some police, fire departments,

54. See Why Do Living Donor Kidney Transplants Offer Better Outcomes?, UnIV. OF MinN. HEALTH (July 5, 2017), https://www.mhealth.org/blog/2017/july-2017/why-do-living-donorkidney-transplants-offer-better-outcomes [perma.cc/7HDU-MCV9].

55. Why Do Living Donor Kidney Transplants Offer Better Outcomes?, UnIV. OF MinN. HeAlth (July 5, 2017), https://www.mhealth.org/blog/2017/july-2017/why-do-living-donorkidney-transplants-offer-better-outcomes [perma.cc/7HDU-MCV9].

56. Id.

57. Id.

58. Id.; Abigail Lefin, Man Makes Urgent Plea for Living Kidney Donor, Receives Over 40 Calls, ABC News 13 WSET (Jan. 16, 2019), https://wset.com/news/local/recent-high-schoolgraduates-urgent-plea-for-living-kidney-donor-receives-over-40-calls [perma.cc/A38F-SWD9].

59. What is a Kidney Transplant?, NAT'L KIDNEY FouND., https://www.kidney.org.uk/organdonation/medical-info-transplant-txwhat/medical-info-transplant-txsurvival/ (last visited Feb. 11, 2019) [perma.cc/2JRF7TAW].

60. Organ Procurement and Transplantation Network Data, supra note 24.

61. Lenny Bernstein, What Makes Someone Donate a Kidney to A Stranger?, WASH. Post (Apr. 28, 2017), https://www.washingtonpost.com/news/to-your-health/wp/2017/04/28/whatmakes-people-donate-a-kidney-to-a-stranger/?utm_term=.10f1982414e1 [perma.cc/RS6K-8F2E].

62. Id.

63. The Living Donation Process, supra note 32.

64. Tong et al., supra note 7. 
and branches of the military will not accept individuals with one kidney. ${ }^{65}$

\section{A. Financial Burdens}

Living organ donors often incur direct and indirect costs associated with donation. ${ }^{66}$ For example, neither the recipient's nor the donor's insurance generally covers lost wages during the donor's recovery, lodging and travel expenses, or follow-up expenses. ${ }^{67}$ The National Center for Biotechnology Information conducted a study and found that 26 percent of living organ donors scored their financial burden as a five-out-of-ten or higher six months after organ donation, based on donation-related out-of-pocket costs and lost income. ${ }^{68}$ The total financial loss to a living donor following donation can range from $\$ 500$ to over $\$ 5,000 .{ }^{69}$ Donors use a variety of sources to help offset these burdens, including dipping into their savings, borrowing from friends or family, taking out a loan, or having a fundraiser. ${ }^{70}$

The Kidney Donor Outcomes Cohort Study, a study established to characterize the short and long term surgical, medical, functional, psychological, and financial outcomes of kidney donation, surveyed 182 living kidney donors and found that 89 percent of the donors had a net financial loss twelve months after surgery. ${ }^{71}$ The study reported a total of $\$ 622,324$ in direct and indirect expenses for the 182 living donors, averaging over $\$ 3,000$ per donor. ${ }^{72}$ Some donors received financial assistance to help offset the financial loss, but the assistance provided only about $\$ 650$ per donor. ${ }^{73}$ Direct expenses included ground transportation, air transportation, lodging, meals, health care, and

65. Benefits and Risks of Becoming A Living Organ Donor, supra note 47; Medical Conditions That Can Keep You from Joining the Military, MiLITARY.COM, https://www.military. com/join-armed-forces/disqualifiers-medical-conditions.html (last visited Nov. 29, 2018) [perma.cc/CW9A-KUJB].

66. J.R. Rodrigue et al., Direct and Indirect Costs Following Living Kidney Donation: Findings from the KDOC Study, KIDNEY DONOR Outcomes COHORT (Feb. 4, 2016), https://onlinelibrary.wiley.com/doi/10.1111/ajt.13591 [perma.cc/C77F-38W6].

67. Financial and Insurance Issues, NAT'L KIDNEY Found., https://www.kidney.org/ transplantation/livingdonors/financial-insurance-issues (last visited Feb. 11, 2019) [perma.cc/ NW7K-A2EJ].

68. J.F. Wiseman et al., Financial Burden Borne by Laparoscopic Living Kidney Donors, NAT'L CTR. FOR BIOTECH. INFO. (Sept. 2017), https://www.ncbi.nlm.nih.gov/pubmed/27941440 [perma.cc/L9B5-NJDU].

69. Direct and Indirect Costs Following Living Kidney Donation: Findings from the KDOC Study, supra note 66.

70. J.F. Wiseman et al., supra note 68.

71. Direct and Indirect Costs Following Living Kidney Donation: Findings from the KDOC Study, supra note 66.

72. $I d$.

73. Id. 
medications.$^{74}$ Indirect expenses encompassed lost wages, including work hours missed, paid vacation time used, sick time hours used, and disability hours used. ${ }^{75}$

Indirect expenses add up quickly for living organ donors because they must take a considerable amount of time off of work to recover from surgery. ${ }^{76}$ Kidney donors usually cannot return to work for two to six weeks following surgery, and liver donors may need up to three months of recovery time. ${ }^{77}$ Although the Family and Medical Leave Act protects an organ donor's job, an employer need not pay for a donor's time off work. ${ }^{78}$ The National Living Donor Assistance Center provides financial support to organ donors, delivering financial assistance to about 5 percent of living kidney donors since its inception. ${ }^{79}$ However, the legislation establishing the program has strict eligibility criteria and specifically prohibits reimbursement of lost wages. ${ }^{80}$ Two-thirds of potential donors who express concern about potential lost income decide not to move forward with the evaluation process. ${ }^{81}$ Thus, the fear of financial loss greatly discourages living organ donation.

\section{B. Insurance Discrimination}

Difficulty obtaining insurance after surgery is also a fear of potential living organ donors. ${ }^{82}$ According to a study in the American Journal of Transplantation, as many as 11 percent of living organ donors experience trouble securing or paying for insurance after their procedures because of discriminatory practices. ${ }^{83}$ In 2008, Wisconsin resident Peter Atkinson made the life-changing decision to donate a kidney to a friend in need. ${ }^{84}$ As a result, two companies later denied him life insurance. ${ }^{85}$ When a third firm determined he was eligible for life insurance, they increased his premium after learning he had been an organ donor despite his

74. Id.

75. Id.

76. See generally Cheryl Jacobs \& Charlie Thomas, Live Donation: Financial Toolkit, AM. SOC'Y OF TRANSPLANTATION (2016), https://www.myast.org/sites/default/files/AST-16-FinancialToolkit-Section-7-Living-Donation-and-Employment.pdf [perma.cc/V3VL-KG4B].

77. Id.

78. Id.

79. Direct and Indirect Costs Following Living Kidney Donation: Findings from the KDOC Study, supra note 66.

80. Id.

81. James R. Rodrigue et al., Concern of Lost Income Following Donation Deters Some from Talking to Potential Living Donors, Progress in Transplantation (Aug. 5, 2016), https://journals.sagepub.com/doi/abs/10.1177/1526924816661332?journalCode=pitb\#articleCit ationDownloadContainer [perma.cc/4PKF-5EJK].

82. See R.C. Yang et AL., InSurability of Living Organ Donors:A Systematic Review 1549 (AMERICAN JOURNAL OF TRANSPLANTATION 2007).

83. Id.

84. Wahlberg, supra note 2.

85. Id. 

ENCOURAGING ORGAN DONATION

good health.$^{86}$ Similarly, in 2013, Virginia resident Cathy Frei was denied long term care insurance when she disclosed on the application that she was being tested to become a living kidney donor ${ }^{87}$ As a precaution, the National Kidney Foundation warns individuals considering organ donation to "check [their] insurance contracts carefully to see if living donation would affect [their] current policies." 88

One reason living organ donors have experienced difficulty obtaining or maintaining insurance following donation is because organ donation is considered a pre-existing medical condition. ${ }^{89}$ Currently, under the Affordable Care Act, health insurance companies cannot refuse to cover an individual because of his or her health history. ${ }^{90}$ However, a pre-existing condition can still affect a donor's access to life insurance and disability insurance and can lead to increased premiums or outright denial of coverage. ${ }^{91}$ Members of the donor community who have experienced insurance discrimination solely based on their status as an organ donor believe that "the threat of increased insurance premiums or canceled policies discourage[s] altruistic people from making a gift capable of saving another person's life." 92

\section{Lack of Knowledge}

Lastly, despite general awareness of living organ donation, "studies using focus groups and focused interviews of the general public consistently identify public misperceptions and lack of knowledge regarding the risks of organ donation." ${ }^{.93}$ Although the majority of the general public support living organ donation, several factors temper this endorsement, including concerns of surgical

86. Id.

87. Cathy Frei, Protecting Living Organ Donors' Rights, The Hill (June 20, 2016, 9:42 $\mathrm{AM}$ ), https://thehill.com/blogs/congress-blog/healthcare/284000-protecting-living-organ-donorsrights [perma.cc/XM4D-ZRB5].

88. Financial and Insurance Issues, supra note 67.

89. German Lopez, I Want to Donate my Kidney. Obamacare Repeal Would Make That a Little Scarier, Vox (May 4, 2017), https:/www.vox.com/policy-and-politics/2017/5/4/15548456/ kidney-donors-ahca-obamacare [perma.cc/HJ9T-PANF].

90. Getting and Keeping Insurance After Live Donation, AM. SOC'Y OF TRANSPLANTATION, http://www.livedonortoolkit.com/financial-toolkit/getting-and-keeping-insurance-after-livedonation [perma.cc/8GBX-22C7].

91. Lopez, supra note 89.

92. Tim Carpenter, Kidney Donor Asks Kansas Legislators to Block Insurance Discrimination, TOPEKA CAP. J. (Jan. 25, 2019), https://www.cjonline.com/news/20190123/kidneydonor-asks-kansas-legislators-to-block-insurance-discrimination [perma.cc/3ZVJ-ENLR].

93. Alexander C. Wiseman, Protecting Donors and Safeguarding Altruism in the United States, Clinical J. OF AM. SoC'Y of NePhrology (May 2018), https://cjasn.asnjournals.org/ content/13/5/790 [perma.cc/4BHA-E5S6]. 
and health risks to the donor and uncertainty about organ donation. ${ }^{94}$ A review of eighteen studies involving 1,019 participants found that the lack of knowledge about the organ donation process and a desire for more information are deterrents to potential organ donors. ${ }^{95}$ Researchers at Emory University conducted a survey on the deterrents to organ donation, and concluded living donor advocates must dispel misperceptions and increase donation to decrease waitlist mortality and improve post-transplantation outcomes. ${ }^{96}$

Currently, the only positive aspects of organ donation advertised for a potential living donor are "positive emotional experiences" and "more time with your loved one." ${ }^{.97}$ Although transplant surgeons and physicians acknowledge the need for providing protections and incentives for living donors, scholars argue that change will not happen without advocates lobbying members of Congress. ${ }^{98}$

\section{CURRENT LAWS PROTECTING LIVING DONORS}

\section{A. Insufficient Federal Law}

In the late 1990s, the Clinton Administration launched the National Organ and Tissue Donation Initiative in efforts to increase organ donations nationwide. ${ }^{99}$ This initiative was furthered by the enactment of the Organ Donor Leave Act of 1999 ("ODLA"), which increased the amount of paid leave available to federal employees from seven days to thirty. ${ }^{100}$ By signing into law the ODLA, President Clinton sought to "enhance the Federal Government's leadership role in encouraging organ donations by making it easier for Federal employees to become donors." 101 Additionally, the President hoped that as the country's largest employer, the federal government would "set the example for the private sector as well as other public organizations." ${ }^{102}$ However, no federal law currently exists requiring private-sector employers to allow paid time off for organ donation. ${ }^{103}$

94. Tong et al., supra note 7.

95. Michelle J. Irving et al., Factors That Influence the Decision to be an Organ Donor: A Systematic Review of the Qualitative Literature, 27 NePhrology Dialysis Transplantation 2526, 2530 (2011).

96. Marty T. Sellers et al., Deterrents to Organ Donation: A Multivariate Analysis of 766 Survey Respondents, 226 J. OF THE AM. C. OF SuRgEONS 414 (2018).

97. Benefits and Risks of Becoming A Living Organ Donor, supra note 47.

98. Keith Humphreys, An Organ Shortage Kills 30 Americans Every Day. Is it Time to Pay Donors?, WASH. POST (Oct. 20, 2014), https://www.washingtonpost.com/news/wonk/wp/2014/ 10/20/an-organ-shortage-kills-30-americans-every-day-is-it-time-to-pay-donors/ [https://perma.cc/C8KA-T3VV].

99. Press Release, Office of the Press Secretary, Statement by the President (Sept. 24, 1999) (on file with author).

100. Organ Donor Leave Act of 1999, Pub. L. No. 106-56, 113 Stat. 407.

101. Press Release, supra note 99.

102. Id.

103. See Donor Leave Laws and Tax Deductions/Credits for Living Donors, NAT'L KIDNEY 
The federal government's effort to help people in need of life-saving organ transplants continued with the Organ Donation and Recovery Improvement Act ("ODRI"). ${ }^{104}$ The ODRI, signed into law by President Bush in 2004, permitted the federal government to award grants for reimbursement of travel expenses, subsistence expenses, and incidental non-medical expenses incurred by individuals who make living organ donations. ${ }^{105}$ Although the Act focused on assisting living organ donors, the law only authorized an appropriation of funds for the years 2005 through 2009. ${ }^{106}$ Moreover, as discussed in Section II, financial assistance programs for living donors are fragmented, inaccessible, and limited in what types of expenses are reimbursable. ${ }^{107}$

No federal legislation currently exists that gives organ donors tax credits or allows for a charitable deduction on their federal income taxes for the value of their organs. ${ }^{108}$ Legislators have proposed legislation over the years to give organ donors a special tax credit, but problems such as valuing donations prevent legislation. ${ }^{109}$ Furthermore, the Internal Revenue Service has allowed only charitable donations for gifts to tax-qualified charities, and this type of legislation would allow deductions for gifts to individuals. ${ }^{110}$

The lack of federal law protecting living donors from financial disincentives is most likely due to the National Organ Transplant Act of 1984 ("NOTA"). NOTA makes it "unlawful for any person to knowingly acquire, receive, or otherwise transfer any human organ for valuable consideration for use in human transplantation." "111 The term "valuable consideration" means anything of material value, but does not include "reasonable payments associated with the removal, transportation, implantation, processing, preservation, quality control, and storage of a human organ or the expenses of travel, housing and lost wages incurred by the donor of human organ in connection with the donation of the organ." 112

FounD., https://www.kidney.org/sites/default/files/LD_Tax_Ded_Leave_5_23_18.pdf(last updated May 22, 2018) [https://perma.cc/D5QY-E3YE]; Living Donor Leave Laws: Federal and State by State, Am. TRANSPLANT FOUND., https://www.americantransplantfoundation.org/wp-content/ uploads/2018/08/living_donor_laws_state_by_state_and_federal.pdf (last updated July 2018) [perma.cc/G8ZV-X685].

104. Organ Donation and Recovery Improvement Act - Signed into Law, Mo. DEP'T. OF

HEALTh \& SENIOR SERVS., https://health.mo.gov/living/organdonor/pdf/04ODAct.pdf [perma.cc/AM2S-SBBQ].

105. Organ Donation and Recovery Improvement Act, Pub. L. No. 216, 118 Stat. 584 (2004).

106. Id.

107. Rodrigue et al., supra note 66.

108. Stephen Fishman, Are There Tax Incentives for Organ Donations?, Nolo, https://www. nolo.com/legal-encyclopedia/are-there-tax-incentives-organ-donations.html (last visited Nov. 29, 2018) [perma.cc/VEC8-K2TJ].

109. Id.

110. Id.

111. National Organ Transplant Act § 301(a), 42 U.S.C. § 274(e) (1984).

112. Id. $\S 301(\mathrm{c})(2)$. 
Although reimbursements are legal under NOTA, "the law's lack of clarity and criminal penalties have [arguably] created the uncertainty that has prevented or delayed reimbursements" to living organ donors. ${ }^{113}$

The most recent federal government initiative to help living organ donors was the clarification of what constitutes a "serious health condition" under the Family and Medical Leave Act. ${ }^{114}$ On August 28, 2018, the U.S. Department of Labor responded to public concern and released a legal opinion stating that "an organ donation can qualify as an impairment or physical condition that is a serious health condition under the FMLA when it involves either 'inpatient care' under $\S 825.114$ or 'continuing treatment' under $\S 825.115$." 115 This statement clarifies that a living donor may take a leave of absence without the risk of being fired. ${ }^{116}$ However, the leave required under the FMLA is unpaid, "and donors lose income if their employer does [not] allow some form of paid time off." 117

\section{B. Inconsistencies in State Law}

Despite the federal government's lack of action, “[m]any states have passed their own legislation to protect living donors and encourage . . . donation."118 Such legislation seeks to protect these individuals in the form of donor leave laws, tax deductions or credits, and living donor protection laws. ${ }^{119}$

1. Paid/Unpaid Leave.-Modeled after the Organ Donor Leave Act of 1999, most state living donor laws offer state government employees up to thirty days of leave for serving as a living organ donor. ${ }^{120}$ However, the exact number of days given to state employees for organ donation recovery is inconsistent across state lines. ${ }^{121}$ Colorado, for example, only allows state employees up to two days per year of paid leave for organ donation as compared to the thirty days that most states allow. ${ }^{122}$ Additionally, state laws allowing government employees to take

113. Cartwright Announces Legislation to Increase Organ Donation, CONGRESSMAN MATT CARTWRIGHT (July 19, 2018), https://cartwright.house.gov/media-center/press-releases/cartwrightannounces-legislation-to-increase-organ-donation [perma.cc/QEB3-Z6LK].

114. Opinion Letter, U.S. Dep't of Labor, FMLA2018-2-A (Aug. 28, 2018) (on file with author).

115. Id.

116. Neergaard, supra note 1.

117. Id.

118. Lavarne A. Burton, States are Protecting Living Organ Donors. Congress Should Follow Suit, STAт (Oct. 30, 2018), https://www.statnews.com/2018/10/30/states-protecting-living-organdonors-congress/ [perma.cc/ZGS6-VSKW].

119. Living Donor Leave Laws: Federal and State by State, supra note 103.

120. See Donor Leave Laws and Tax Deductions/Credits for Living Donors, supra note 103; Living Donor Leave Laws: Federal and State by State, supra note 103.

121. See Donor Leave Laws and Tax Deductions/Credits for Living Donors, supra note 103; Living Donor Leave Laws: Federal and State by State, supra note 103.

122. See Donor Leave Laws and Tax Deductions/Credits for Living Donors, supra note 103; Living Donor Leave Laws: Federal and State by State, supra note 103; CoLO. REV. STAT. § 24-50- 
time off for organ donation do not always require that the leave be paid. State government employers in the state of Maine, for example, have the discretion to provide their employees with either paid or unpaid leave. ${ }^{123}$

The inconsistencies in state organ donor leave laws are even greater for private sector employees. Fewer than a quarter of all states provide organ donor leave laws for private-sector employees. ${ }^{124}$ Furthermore, only three states require private-sector employers to offer paid time off to employees recovering from organ donation. ${ }^{125}$ For example, California and Hawaii require that employees receive up to thirty days of paid leave, while Minnesota employees receive up to forty hours of paid leave. ${ }^{126}$

2. Employer Tax Credit.-Perhaps the main reason states are reluctant to extend paid time off to private sector employees for organ donation is the economic burden it places on the employer. ${ }^{127}$ Thus, some states provide help to employers of living organ donors (see Table 1). ${ }^{128}$ Arkansas, Colorado, Pennsylvania, and the District of Columbia offer tax incentives to employers who choose to pay their employees for time off related to organ donation. ${ }^{129}$ Colorado allows employers to claim a tax credit equal to 35 percent of expenses incurred "[p]aying an employee during his or her leave of absence period" or "for the cost of temporary replacement help." 130 Arkansas and the District of Columbia allow a tax credit of a similar percentage to employers providing time off to organ donors. ${ }^{131}$ Pennsylvania goes as far as allowing employers to take a credit equal to $100 \%$ of wages paid to an employee on leave for organ donation, and temporary employees hired. ${ }^{132}$ By allowing tax credits, private-sector employees may give more thought to offering paid time off to employees recovering from

104 (2017).

123. Me. Rev. Stat. AnN. tit. 26, § 844 (2007).

124. Mabe, supra note 23.

125. Donor Leave Laws and Tax Deductions/Credits for Living Donors, supra note 103; Living Donor Leave Laws: Federal and State by State, supra note 103.

126. Cal. Lab Code $\S 1510$ (Deering 2012); Haw. Rev. Stat. AnN. § 398A-3 (LexisNexis 2014); Minn. Stat. AnN. § 181.945 (1990).

127. See generally Robert Henneke, The High Economic Burden of Paid Sick Leave, Tex. PuB. Pol. Found. (May 11, 2018), https:/www.texaspolicy.com/the-high-economic-burden-ofpaid-sick-leave/ [perma.cc/7QBV-CDRS]; Ron French, Paid Sick Leave Law Making Some Michigan Businesses Feel Queasy, BRIDGE (Oct. 18, 2018), https://www.bridgemi.com/publicsector/paid-sick-leave-law-making-some-michigan-businesses-feel-queasy [perma.cc/5V7L53RM].

128. See Donor Leave Laws and Tax Deductions/Credits for Living Donors, supra note 103; Living Donor Leave Laws: Federal and State by State, supra note 103.

129. Ark. Code Ann. § 11-3-205 (2005); Colo. Rev. Stat. § 39-22-540 (2017); D.C. Code $\S 47-1807.08$ (2009); 35 PA. Cons. STAT. § 6120.3 (2006).

130. § 39-22-540.

131. § 11-3-205; § 47-1807.08.

132. $\S 6120.3$. 
organ donation, thus preventing organ donors from facing financial hardships as a result of donating.

Table 1: Leave Laws Affecting Private-Sector Employers:

\begin{tabular}{|c|c|c|}
\hline State & $\begin{array}{c}\text { Paid Time Off: Optional } \\
\text { or Required? }\end{array}$ & Tax Credits to Employer? \\
\hline Arkansas & Optional & $\begin{array}{l}25 \% \text { of salary paid to donor/for } \\
\text { replacement help }{ }^{133}\end{array}$ \\
\hline California & Required - 30 days ${ }^{134}$ & None \\
\hline Colorado & Optional & $\begin{array}{l}35 \% \text { of salary paid to donor/for } \\
\text { replacement help }\end{array}$ \\
\hline District of Columbia & Optional & $\begin{array}{c}25 \% \text { of salary paid to donor up to } 30 \\
\text { days }^{136}\end{array}$ \\
\hline Hawaii & Required - 30 days $^{137}$ & None \\
\hline Minnesota & Required -40 hours ${ }^{138}$ & None \\
\hline Pennsylvania & Optional & $\begin{array}{c}100 \% \text { of salary paid to donor/for } \\
\text { replacement help }{ }^{139}\end{array}$ \\
\hline
\end{tabular}

3. Donor Tax Credits and Deductions. - In addition to employer credits, nineteen states currently provide special tax breaks to residents who donate kidneys, portions of their liver, intestines, or bone marrow for transplantation. ${ }^{140}$ Tax credits are perhaps the most appealing tax incentive provided to living organ donors, and four states offer these credits: Idaho, Louisiana, Maryland, and Utah (see Table 2).

133. § 11-3-205.

134. CAL. Lab Code $\S 1510$ (Deering 2012).

135. § 39-22-540.

136. D.C. CoDE $\S 47-1807.08$ (2009).

137. Haw. Rev. Stat. AnN. § 398A-3 (LexisNexis 2014).

138. Minn. Stat. Ann. § 181.945 (1990).

139. 35 PA. Cons. STAT. $\S 6120.3$ (2006).

140. Donor Leave Laws and Tax Deductions/Credits for Living Donors, supra note 103; Living Donor Leave Laws: Federal and State by State, supra note 103. 

ENCOURAGING ORGAN DONATION

Table 2: Tax Credits for Living Organ Donors

\begin{tabular}{|c|c|c|c|c|}
\hline State & $\begin{array}{c}\text { Tax Credit } \\
\text { Amount }\end{array}$ & Included Expenses & $\begin{array}{c}\text { Option to Carry } \\
\text { Over Unused } \\
\text { Credit? }\end{array}$ & $\begin{array}{c}\text { Who Can } \\
\text { Claim Tax } \\
\text { Credit? }\end{array}$ \\
\hline Idaho & $\begin{array}{c}\text { Up to } \\
\$ 5,000^{141}\end{array}$ & $\begin{array}{c}\text { Unreimbursed } \\
\text { travel, lodging, and } \\
\text { lost wages }{ }^{142}\end{array}$ & $\begin{array}{l}\text { Yes. Up to five } \\
\text { taxable years. }{ }^{143}\end{array}$ & Donor $^{144}$ \\
\hline Louisiana & $\begin{array}{c}\text { Up to } \\
\$ 7,2000^{145}\end{array}$ & $\begin{array}{c}\text { Unreimbursed } \\
\text { travel, lodging, and } \\
\text { lost wages }{ }^{146}\end{array}$ & $\begin{array}{l}\text { Yes. Up to ten } \\
\text { taxable years. }{ }^{147}\end{array}$ & $\begin{array}{c}\text { Donor or their } \\
\text { spouse }^{148}\end{array}$ \\
\hline Maryland & $\begin{array}{c}\text { Up to } \\
\$ 7,500^{149}\end{array}$ & $\begin{array}{l}\text { Unreimbursed } \\
\text { travel, lodging, and } \\
\text { lost wages }{ }^{150}\end{array}$ & No. & Donor $^{151}$ \\
\hline Utah & $\begin{array}{c}\text { Up to } \\
\$ 10,000^{152}\end{array}$ & $\begin{array}{l}\text { Unreimbursed } \\
\text { travel, lodging, and } \\
\text { lost wages }{ }^{153}\end{array}$ & $\begin{array}{l}\text { Yes. Up to five } \\
\text { taxable years }^{154}\end{array}$ & $\begin{array}{c}\text { Donor or their } \\
\text { parent }^{155}\end{array}$ \\
\hline
\end{tabular}

The amount of tax credits a taxpayer may claim varies from the four applicable states, ranging from $\$ 5,000$ to $\$ 10,000 .{ }^{156}$ Utah and Louisiana allow taxpayers other than the donor to take a credit. ${ }^{157}$ In the event the amount of a tax credit exceeds the taxpayer's income tax, liability may be carried forward to subsequent taxable years in Idaho, Louisiana, and Utah. ${ }^{158}$

141. IDAHO CODE $\S 63-3029 \mathrm{~K}$ (2006).

142. Id.

143. Id.

144. Id.

145. La. Stat. ANN. § 47:297 (2017).

146. Id.

147. Id

148. Id.

149. H.B. 96, 2018 Leg., 2018 Sess. (Md. 2018).

150. Id.

151. Id.

152. UTAH CODE ANN. § 59-10-1015 (2008).

153. Id.

154. Id

155. Id.

156. Id.; IDAHO CODE $\S 63-3029$ K (2006); LA. StAT. AnN. § 47:297 (2017); H.B. 96, 2018 Leg., 2018 Sess. (Md. 2018).

157. § 47:297; § 59-10-1015.

158. $\S 63-3029 \mathrm{~K} ; \S 47: 297 ; \S 59-10-1015$. 
Another way states are using tax breaks to protect living organ donors from financial hardship is by allowing above-the-line tax deductions. ${ }^{159}$ Fifteen states offer a deduction of up to $\$ 10,000$ for costs related to the taxpayer's donation. ${ }^{160}$ A few states even offer a deduction for costs related to a donation by a dependent of a taxpayer. ${ }^{161}$ Like tax credits, deductible costs commonly include the cost of unreimbursed travel, lodging, and lost wages. ${ }^{162}$ Unfortunately, due to low state marginal income tax rates, these tax deductions are only worth about $\$ 650$, far less than the actual cost of organ donation. ${ }^{163}$

4. Protection from Discrimination.- Some states have gone even further to incentivize living organ donation. On March 20, 2018, Idaho became the first state to pass legislation similar to the proposed Living Donor Protection Act. ${ }^{164}$ The Idaho legislation, Senate Bill 1302, is recognized as the first law in the nation designed to stop the insurance discrimination organ donors face, despite being "healthier than the U.S. population at large." 165 Specifically, the law makes it unlawful to "discriminate against a person in the offering, issuance, cancellation, price or conditions of a policy, or in the amount of coverage provided under a policy" based solely on the status of such person as a living organ donor. ${ }^{166}$ Following in Idaho's footsteps, New York Governor Andrew Cuomo signed into law the New York Living Donor Protection Act in November of 2018. ${ }^{167}$ In addition to protecting living donors from insurance discrimination, the law provides clarification that New York's paid family leave program will cover organ donation and requires that the New York Commissioner of Health develop informational materials relating to the benefits of organ donation. ${ }^{168}$

159. Donor Leave Laws and Tax Deductions/Credits for Living Donors, supra note 103; Living Donor Leave Laws: Federal and State by State, supra note 103. An above-the-line deduction is money subtracted from your income before your adjusted gross income is calculated for tax purposes.

160. Sally Satel \& Alan D. Viard, The Kindest (Tax) Cut: A Federal Tax Credit for Organ Donations, 11 TAXNotes 1623, 1627 (June 12, 2017).

161. Id.

162. Id.

163. Fishman, supra note 108.

164. Idaho First in Nation to Pass Living Donor Protections, NAT'L Kidney Found., https://www.kidney.org/news/national-kidney-foundation-statement-landmark-legislation-signedidaho-governor-to-protect (last visited Nov. 30, 2018) [perma.cc/NCD7-2ZT8].

165. Id.

166. IDAHO CODE $\S 41-1852$ (2018).

167. New York Passes Living Donor Protection Act, NAT'L Kidney Found. (Nov. 8, 2018), https://www.prnewswire.com/news-releases/new-york-passes-living-donor-protection-act300746732.html [perma.cc/Y3WB-HZBB].

168. Id. 


\section{PROPOSED FEDERAL LEGISLATION}

\section{A. Living Donor Protection Act}

U.S. Representatives Jerrold Nadler and Jaime Herrera Beutler first introduced the Living Donor Protection Act ("LDPA" or "the Act") in 2014. ${ }^{169}$ Nadler and Beutler introduced the LDPA to protect the rights of living organ donors. ${ }^{170}$ The two members of Congress advocate that, through this bipartisan legislation, "living organ donors will be able to access insurance and use the medical leave they need, giving donors more certainty and, it is [their] hope, encourage more Americans to give the incredible gift of organ donation." 171 The Act aims to protect living organ donors and promotes organ donation in three ways. ${ }^{172}$ First, the LDPA prohibits life, disability, and long-term care insurance companies from denying or limiting coverage and from charging higher premiums for living organ donors. ${ }^{173}$ The LDPA reads:

It shall be unlawful to . . . discriminate in the offering, issuance, cancellation, amount of such coverage, price, or any other condition of a life insurance policy, disability insurance policy, or long-term care insurance policy for a person, based solely and without any additional actuarial risk upon the status of such person as a living donor. ${ }^{174}$

Second, the Act clarifies that living organ donors may use Family and Medical Leave Act time to recover from the surgeries and procedures involved in their donation. ${ }^{175}$ The U.S. Department of Labor's statement, discussed in Section III.A, was a direct response to the bill provision authored by Nadler and Beutler. ${ }^{176}$ The National Kidney Foundation praised Beutler following the opinion letter and thanked her for her "leadership in ensuring the job security of living donors who are eligible for FMLA."177 The Congresswoman said she would use

169. H.R. 1270: Living Donor Protection Act of 2017, GovTrack, https://www.govtrack.us/ congress/bills/115/hr1270 (last visited Oct. 18, 2018) [perma.cc/XM7D-2XWY].

170. Living Donor Protection Act Introduced, supra note 11.

171. Id.

172. Nadler, Herrera Beutler Introduce Bipartisan Living Donor Protection Act to Protect Organ Donors, CONGRessman JERROLD NADLER (Mar. 1, 2017), https://nadler.house.gov/pressrelease/nadler-herrera-beutler-introduce-bipartisan-living-donor-protection-act-protect-organ [perma.ce/5QTY-5JT4].

173. $I d$.

174. Living Donor Protection Act of 2017, H.R. 1270, 115th Cong. $§ 2$ (2017).

175. Nadler, Herrera Beutler Introduce Bipartisan Living Donor Protection Act to Protect Organ Donors, supra note 172.

176. Katy Sword, Live Organ Donors Protected Under FMLA, The Columbian (Sept. 5, 2018), https://www.columbian.com/news/2018/sep/05/live-organ-donors-protected-under-fmla/ [perma.cc/HFN7-MGUN].

177. Id. 
this positive development "to continue championing the Living Donor Protection Act." 178

Third, the LDPA directs the Secretary of Health and Human Services to update its materials on live organ donation to reflect these new protections and encourage more individuals to consider donating an organ. ${ }^{179}$ The Act requires that the updated materials include "(1) the benefits of live organ donation; and (2) the impact of live organ donation on the access of a living organ donor to insurance." ${ }^{180}$ Further, it requires that HHS "shall update, as appropriate (1) public service announcements...(2) publicly accessible websites... and (3) other media determined appropriate by the Secretary."

Despite Nadler and Beutler's persistent efforts to pass the legislation, the Living Donor Protection Act has yet to be successful. The 2014 version of the Act, House Resolution 5263, died in the Committee on Education and the Workforce. ${ }^{182}$ Nadler and Beutler proposed the Act again in $2016 .{ }^{183}$ The 2016 version of the Act, House Resolution 4616, died in the Committee on Energy and Commerce. ${ }^{184}$ The most recent version of the bill, House Resolution 1270, was introduced in the House of Representatives on March 1, 2017 and referred to five committees: Energy and Commerce; Oversight and Government Reform; House Administration; Education and the Workforce; and Financial Services. ${ }^{185}$ The Committee on Energy and Commerce subsequently referred the bill to the Subcommittee on Health on March 17, 2017. ${ }^{186}$ Experts predicted the Act only had a 4 percent chance passing Congress, ${ }^{187}$ and due to lack of action, the executive deadline passed and House Resolution 1270 died in the Subcommittee on Health at the end of $2018 .{ }^{188}$ Nadler and Beutler introduced the bill in the House for the fourth time in February 2019. ${ }^{189}$

\section{B. Organ Donor Clarification Act}

In another effort to address the Nation's organ shortage, U.S. Representative

178. Id.

179. Nadler, Herrera Beutler Introduce Bipartisan Living Donor Protection Act to Protect Organ Donors, supra note 172.

180. Living Donor Protection Act of 2017, H.R. 1270, 115th Cong. § 4 (2017).

181. Id.

182. Living Donor Protection Act of 2014, H.R. 5263, 113th Cong. (2014).

183. H.R. 1270: Living Donor Protection Act of 2017, supra note 169.

184. Living Donor Protection Act of 2016, H.R. 4616, 114th Cong. (2016).

185. H.R. 1270.

186. H.R. 1270 - Living Donor Protection Action 2017, Congress.gov, https://www. congress.gov/bill/115th-congress/house-bill/1270 (last visited Sept. 26, 2019) [https://perma.cc/ BX9A-VK9E].

187. H.R. 1270: Living Donor Protection Act of 2017, supra note 169.

188. H.R. 1270.

189. Living Donor Protection Act of 2019, H.R. 1224, 116th Cong. (2019). 
Matt Cartwright introduced the Organ Donor Clarification Act. ${ }^{190}$ The bill, first introduced by Cartwright in 2016, seeks to amend the National Organ Transplant Act to clarify the definition of valuable consideration and to clarify that pilot programs that honor and reward organ donation do not violate NOTA. ${ }^{191}$

According to Cartwright, "[c]onfusion about what constitutes valuable consideration hampers donation by scaring people away from reimbursing organ donors for things like medical expenses and lost wages." 192 The Act amends Section 301(c)(2) of NOTA by adding a list of reimbursements that are not considered "valuable consideration." 193 These additions include all medical expenses, follow-up care, and medication related to donation, advanced payment or reimbursement for pre and post-transplant care, reimbursements for food and other logistical expenses related to donation, and paperwork or legal costs related to donation. ${ }^{194}$ Cartwright believes that by clarifying that certain types of payments are not valuable consideration but are reimbursements for expenses a donor incurs, the Act would remove the financial barriers confronting living organ donors. ${ }^{195}$

In addition to amending the definition of valuable consideration, the Organ Donor Clarification Act adds a section to NOTA that would allow the government to encourage organ donation through noncash benefits provided by a pilot program. ${ }^{196}$ For the purpose of the Act, the term "pilot program" is a program approved by the Secretary of Health and Human Services for the purpose of "measuring the effect of removing disincentives or providing a noncash benefit that may increase the organ pool." 197 These pilot programs would test the effectiveness of providing non-cash incentives to promote organ donation and would have to pass ethical board scrutiny. ${ }^{198}$ The most recent version of the bill, introduced in July of 2018, died in the House Committee on Energy and Commerce. ${ }^{199}$

\section{CRITICISMS OF FEDERAL AND STATE LEGISLATION}

Although the Living Donor Protection Act has died in Congress three sessions in a row, the bill now has overwhelming, bipartisan support. The bill's drafters, Nadler and Beutler, come from opposing political parties. ${ }^{200}$ Of the

190. Organ Donor Clarification Act of 2018, H.R. 6448, 115th Cong. (2018).

191. Id.

192. Cartwright Announces Legislation to Increase Organ Donation, supra note 113.

193. H.R. 6448.

194. Id.

195. Cartwright Announces Legislation to Increase Organ Donation, supra note 113.

196. H.R. 6448.

197. Id.

198. Cartwright Announces Legislation to Increase Organ Donation, supra note 113.

199. H.R. 6448.

200. H.R. 1270: Living Donor Protection Act of 2017, supra note 169. 
legislation's eighty-seven total co-sponsors, fifty-nine were Democratic Representatives and twenty-eight were Republican Representatives. ${ }^{201}$ Outside organizations and groups have broadly supported all three versions of the bill. ${ }^{202}$ Similarly, when Representative Matthew Cartwright proposed the Organ Donor Clarification Act, the bill had sixteen sponsors: seven Republican Representatives and nine Democratic Representatives. ${ }^{203}$ Furthermore, the U.S. Government of Information on Organ Donation and Transplantation reports that 95 percent of U.S. adults support organ donation. ${ }^{204}$ So, why do these two critical pieces of legislation keep dying in committee?

\section{A. Criticisms of the Living Donor Protection Act}

1. FMLA Provision is Unnecessary.-Passing the Living Donor Protection Act may not be high on Congress's agenda because of the recent opinion released by the U.S. Department of Labor. ${ }^{205}$ A central provision of the Living Donor Protection Act was its clarification that organ donation surgery would qualify as a serious health condition under the Family and Medical Leave Act. ${ }^{206}$ Before the Department of Labor released this statement, organ donation was not explicitly listed as a serious health condition, and it was not clear whether a person was entitled to leave following donation. ${ }^{207}$ The FMLA provision in the Living Donor Protection Act was meant to clarify this confusion, but the U.S. Department of Labor's recent opinion makes this section unnecessary.

2. Is Insurance Discrimination Justified? - Another central provision in the Living Donor Protection Act is its prohibition on the denial of coverage or increase in premiums for life or disability insurance for living organ donors. ${ }^{208}$ Those who oppose the LDPA argue "that organ donation does, in fact, constitute a health condition that should be considered when underwriting insurance policies."209 Unfortunately, doctors cannot predict with certainty whether a healthy donor will later develop complications from the procedure, such as high blood pressure. ${ }^{210}$ However, organ donors "are the healthiest people in the

201. Id.

202. See e.g., ANNA Supports the Living Donor Protection Act of 2017, Am. NePHROLOGY NURSES ASS'N, https://www.annanurse.org/download/reference/health/livingDonorActFactSheet. pdf (last visited Feb. 10, 2019) [perma.cc/4LHG-6EPR]; Support HR 4616 \& S2584 The Living Donor Protection Act, CHANGE.ORG (Feb. 25, 2016), https://www.change.org/p/support-hr-4616-s2584-the-living-donor-protection-act [perma.cc/VS7E-TPEE].

203. H.R. 6448.

204. Organ Donation Statistics, supra note 6.

205. Opinion Letter, U.S. Dep't of Labor, FMLA2018-2-A (Aug. 28, 2018) (on file with author).

206. Living Donor Protection Act of 2017, H.R. 1270, 115th Cong. § 3 (2017).

207. Family and Medical Leave Act of 1993, 29 U.S.C. $\S 2601$ (2012).

208. H.R. $1270 \S 2$.

209. Wiseman, supra note 93.

210. Swee-Ling Levea, What Potential Donors Need to Know About Living Kidney Donation, 
nation," ${ }^{211}$ due to the extensive evaluation process a potential donor must undergo before consideration. Doctors are extremely selective in who can donate, and "[they] keep a close eye on donors for at least two years after donation to ensure their quality of life is at or above what it was before" the procedure. ${ }^{212}$

Dr. Dorry L. Segev, a transplant surgeon at the Johns Hopkins University School of Medicine, conducted a study of the survival rates of kidney donors over a fifteen-year period. ${ }^{213}$ Segev examined the outcomes of 80,347 live kidney donors between 1994 and 2009 to determine the risk of death within ninety days of surgery and found that the death risk was 3.1 per 10,000 donors. ${ }^{214}$ At the conclusion of Segev's study, he determined that "donating a kidney is safer than undergoing almost any other operation." ${ }^{215}$ Living donation has not been linked to a shorter life expectancy, and donating a kidney does not increase a donor's risk of kidney failure. ${ }^{216}$ Furthermore, most donors can return to activities such as yoga, swimming, running, and even drinking within a few months after donation. ${ }^{217}$

Denying life insurance to living organ donors also "makes poor financial sense for insurance companies." ${ }^{218}$ The most common source of difficulty for live kidney donors is the ability to obtain life insurance, despite having lower death rates than the general population. ${ }^{219}$ Approximately 25 percent of organ donors report difficulty obtaining or maintaining policies, even though they are the perfect candidates for life insurance. ${ }^{220}$ Thus, prohibiting insurance discrimination would benefit both the organ donor and the insurer.

3. Educational Efforts and Increasing Donations.-The fourth provision in the Living Donor Protection Act updates the educational materials on the benefits

UT Sw. Med. Cent. (Nov. 30, 2017), https://utswmed.org/medblog/living-kidney-donation/ [perma.cc/P2VM-CQMG].

211. Kathryn Doyle, Some Kidney Donors Struggle to Buy Life Insurance: Study, ReUTERS (July 16, 2014), https:/www.reuters.com/article/us-kidney-donor-insurance/some-kidney-donorsstruggle-to-buy-life-insurance-study-idUSKBN0FL1ZK20140716 [perma.cc/5D4W-8ZZA].

212. Levea, supra note 210.

213. Donating a Kidney Doesn't Shorten Donor's Life, LIVE ScI. (Mar. 9, 2010), https://www.livescience.com/6191-donating-kidney-shorten-donor-life.html [perma.cc/JF2V$72 \mathrm{YL}]$.

214. Id.

215. Id.

216. What to Expect After Donation, NAT'L KIDNEY Found., https:/www.kidney.org/ transplantation/livingdonors/what-expect-after-donation [perma.cc/R587-ZE6Z] (last visited Nov. 30, 2018).

217. Levea, supra note 210.

218. Brian J. Boyarsky et al., Experiences Obtaining Insurance After Live Kidney Donation, 14 Am. J. Transplant 2168, 2173 (2014).

219. Id.

220. Id. at 2171. 
of organ donation. ${ }^{221}$ Critics argue that "the public is a stakeholder group that does not have a direct personal or professional vested interest in increasing donation rates." ${ }^{, 22}$ Dr. Sally Satel, a resident scholar at the American Enterprise Institute, believes that "making living donation financially neutral would help people who already donate, but it wouldn't increase living donation enough to help." 223 Satel stands behind the proposition that in order to increase donation rates, the National Organ Transplant Act needs to be reformed to allow donors to be paid for their organs. ${ }^{224}$

Advocates of greater educational efforts argue that the general public has misconceptions about living donation and sometimes does not even know about the option. ${ }^{225}$ For example, some Americans do not realize they can live with only one kidney. ${ }^{226}$ These supporters blame the lack of federally sponsored public education campaigns covering living donation. ${ }^{227}$ Although the United Network for Organ Sharing is responsible for educating the public on organ donation, these campaigns focus on deceased donation. ${ }^{228}$

\section{B. Criticisms of the Organ Donor Clarification Act}

1. Failure to Define "Noncash Benefit."-The ODCA allows for the federal government to initiate covered pilot programs to measure "the effect of removing disincentives or providing a noncash benefit" to organ donors. ${ }^{229}$ One major criticism of the Act is that the bill is too vague as to what would be considered a noncash benefit. ${ }^{230}$ The National Kidney Foundation released a statement opposing the provision, stating that "the bill does not define what a "non-cash benefit' is thus leaving the interpretation too open and subject to abuse." 231 The Foundation further argues that too much interpretation "could have the unintended consequence of doing harm to both the donor, and transplant

221. Living Donor Protection Act of 2017, H.R. 1270, 115th Cong. § 4 (2017).

222. Tong et al., supra note 7 .

223. Wahlberg, supra note 2.

224. Id.

225. Elisa Gordon, Living Donors Can Save Lives-and Have the Greatest Potential to Combat Our Organ Shortage, PAC. STANDARD (Nov. 14, 2014), https://psmag.com/socialjustice/living-donors-can-save-lives-greatest-potential-combat-organ-shortage-94293 [perma.cc/N43C-HPRD].

226. $I d$.

227. Id.

228. $I d$.

229. Organ Donation Clarification Act of 2018, H.R. 6448, 115th Cong. § 3(a) (2018).

230. John Gregory, Organ Donation Programs Could Offer Reimbursements Under New Bill, HeAlthEXeC (May 27, 2016), https://www.healthexec.com/topics/policy/organ-donationprograms-could-offer-reimbursements-under-new-bill [perma.cc/QR43-2CVD].

231. National Kidney Foundation Statement on The Organ Donation Clarification Act of 2016, NAT'L KIDNEY FOUND. (May 25, 2016), https://www.kidney.org/news/national-kidney-foundationstatement-organ-donation-clarification-act-2016 [perma.cc/TKB5-JPCS]. 
recipient, alike." ${ }^{232}$

Cartwright's failure to define a noncash benefit under the Act allows the Department of Health and Human Services to determine the exact details of those incentives. ${ }^{233}$ The Act requires that these five-year pilot programs be approved by the Secretary of Health and Human Services and be subject to an ethical review process. ${ }^{234}$ The Representative has proposed, however, that these noncash benefits include incentives "such as contributions to a retirement fund or forgiving a portion of a donor's [student] loan debt." 235

2. No Protection for Living Organ Donors.-Although the Organ Donor Clarification Act would allow the government to test incentives through the covered pilot programs, the ODCA would do little to protect living organ donors after donation. ${ }^{236}$ Critics argue that Cartwright's proposed legislation is misdirected because it encourages donation without first providing basic donor protections. ${ }^{237}$ Founder of the American Living Organ Donor Fund, Sigrid FryRevere, believes that "[launching] incentive studies and media campaigns before a proper safety net is in place could be courting disaster" and could lead to dozens, if not "hundreds of angry and frustrated living organ donors." ${ }^{238}$ Living organ donors sometimes suffer financial and medical complications following donation, and critics argue that it would be a mistake to not make sure there are protections in place before the government starts encouraging Americans to take the risks associated with organ donation. ${ }^{239}$

\section{Criticism of State Laws}

1. Tax Breaks for Organ Donors Aren't Increasing Donation.- -Some critics argue that allowing incentives that encourage organ donation, such as tax credits and deductions, do not boost transplant supply. ${ }^{240}$ Studies assessing the impact of state laws that provide tax benefits to organ donors have found that these policies

232. $I d$.

233. Laura Olson, Matt Cartwright Proposes Incentives to Spur New Organ Donors, ThE MORNING CALL (May 31, 2016, 4:16 PM), https:/www.mcall.com/news/nationworld/pennsylvania/ mc-pa-cartwright-organ-donation-bill-20160531-story.html [perma.cc/MG8P-JR6R].

234. H.R. 6448 § $3(\mathrm{a})$.

235. Olson, supra note 233.

236. H.R. 6448.

237. Sigrid Fry-Revere, Where's the Safety Net? Living Organ Donors Are People, Too, HufFington POst (June 27, 2016, 8:21 PM), https://www.huffingtonpost.com/sigrid-fryrevere/living-organ-donors-are-people_b_10229038.html [perma.cc/9x92-DB3Y].

238. Id.

239. Id.

240. Richard Knox, Tax Breaks For Organ Donors Aren't Boosting Transplant Supply, NPR (Aug. 31, 2012, 8:46 AM), https://www.npr.org/sections/health-shots/2012/08/30/160338259/taxbreaks-for-organ-donors-arent-boosting-transplant-supply [perma.cc/Y9LM-3TB8]. 
have little to no effect on increasing organ donation and transplantation. ${ }^{241}$ However, scholars hypothesize that the tax incentives are not working because the cash value of the incentives may be too low to defray costs donors face. ${ }^{242}$ For example, a tax deduction of $\$ 10,000$ for a family of four at the median income level translates to a cash value of only $\$ 600 .{ }^{243}$ Meanwhile, the financial burden for a living kidney donor in the U.S. ranges from $\$ 907$ to $\$ 3,089 .^{244}$ The study also suggests that the public lacks awareness about the existence of these policies and therefore rarely takes advantage of them. ${ }^{245}$ Furthermore, the study looked only at donation rates within two years of passage, and it may take longer for changes in tax law to have an effect. ${ }^{246}$

2. A Violation of Federal Law.-State laws providing tax breaks to living organ donors have left states wondering if the federal government will view these incentives as payment for an organ. ${ }^{247}$ If so, tax credits and deductions would violate the National Organ Transplant Act. ${ }^{248}$ Critics argue that reimbursement for incidental costs of being a living donor, paid time off work, and tax breaks are all benefits labeled as "valuable consideration" under NOTA. ${ }^{249}$ A collaborative paper by the University of California Merced Economics Professor Kurt Schnier suggests similar ideas for removing barriers for donors; however, these ideas would require redefining "valuable consideration." 250

\section{THE IDEAL LEGISLATION: PROVIDING PROTECTION AND INCENTIVES}

Living organ donors provide a valuable gift to society, but many potential donors face formidable disincentives and barriers that discourage donation. ${ }^{251}$ Several states have enacted laws to help eliminate these challenges, and U.S.

241. See A. S. Venkataramani et al., The Impact of Tax Policies on Living Organ Donations in the United States, 12 Am. J. of Transplantation 2133, 2133 (2012); Paula Chatterjee et al., The Effect of State Policies on Organ Donation and Transplantation in the United States, 175 JAMA Internal Medicine, 1323, 1323 (2015).

242. Venkataramani et al., supra note 241.

243. $I d$.

244. Id.

245. Id.

246. Id.; Knox, supra note 240.

247. Kari Jahnsen, Organ Donation Tax Credits: A Life or Death Proposal?, Tax Found. (June 7, 2017), https://taxfoundation.org/organ-donation-tax-credits/ [perma.cc/8WSD-6PEX].

248. Id.

249. Lorena Anderson, Researchers Examine Barriers to Organ Donation and Possible Remedies, UnIV. OF CAL. MERCED (Apr. 16, 2018), https://news.ucmerced.edu/news/2018/ researchers-examine-barriers-organ-donation-and-possible-remedies [perma.cc/3UC4-ZBTP].

250. Id.

251. Shivam Joshi et al., Reciprocating Living Kidney Donor Generosity: Tax Credits, Health Insurance, and an Outcomes Registry, 9 CLINICAL KIDNEY J. 168 (Feb. 2016), https://academic. oup.com/ckj/article/9/1/168/2462461 [perma.cc/X45W-XSYA]. 
representatives are lobbying for the federal government to do the same. ${ }^{252}$ The intent of both the Living Donor Protection Act and the Organ Donor Clarification Act is to increase the number of living organ donors. ${ }^{253}$ The LDPA seeks to do this by providing living donor protections, while the ODCA seeks to do this by providing incentives to potential organ donors. ${ }^{254}$ Both bills include important provisions, such as the prohibition on insurance discrimination and the need to test incentives to organ donation. However, as critics point out, the drafters of these bills have left gaps in their proposed legislation. ${ }^{255}$ Apprehensions about the LDPA include its ability to increase donation. ${ }^{256}$ Apprehensions about the ODCA include its failure to provide protections to organ donors following donation. ${ }^{257}$ If the Living Donor Protection Act and the Organ Donor Clarification Act are both enacted, Congress can eliminate these concerns and provide both the protections and incentives necessary to increase organ donation.

\section{A. Federal Law}

1. Provide Protection Through the Living Donor Protection Act.-Congress should enact the Living Donor Protection Act to guarantee that living donors are protected from financial loss and discrimination following organ donation. As discussed thoroughly in Section II of this Note, living organ donors frequently find themselves with an enormous financial burden and often have trouble obtaining insurance due to their decision to donate. The LDPA makes it illegal to discriminate in the offering, issuance, cancellation, amount of coverage, price, or any other condition of a life insurance policy, disability insurance policy, or long-term care insurance policy for a person, based solely on their status as a living organ donor. ${ }^{258}$ Consequently, the Act will help ease these financial burdens by providing protection to living organ donors.

The LDPA standing alone is the first step to increasing organ donation rates. Evidence suggests that the donor's concern in obtaining or maintaining life, disability, and health insurance may negatively influence his or her decision to donate. ${ }^{259}$ A broad survey of 536 kidney donors found that donors whose insurance premiums increased after donation were less likely to reaffirm their decision to donate. ${ }^{260}$ Further, 39 percent of transplant centers report having had

252. See Donor Leave Laws and Tax Deductions/Credits for Living Donors, supra note 103; Living Donor Protection Act of 2017, H.R. 1270, 115th Cong. (2017); Organ Donation Clarification Act of 2018, H.R. 6448, 115th Cong. (2018).

253. See H.R. 1270; H.R. 6448.

254. H.R. 1270; H.R. 6448.

255. See generally Wahlberg, supra note 2; Fry-Revere, supra note 236.

256. Wahlberg, supra note 2.

257. Fry-Revere, supra note 237.

258. Living Donor Protection Act of 2019, H.R. 1224, 116th Cong. (2019).

259. See YANG ET AL., supra note 82.

260. Id. 
donors decline donation for fear of future medical problems related to lack of health insurance. ${ }^{261}$ The best way to protect living organ donors against insurability issues and thus increase donation is through the introduction of clear and fair heath policies. ${ }^{262}$

Enacting a version of the LDPA will also encourage donation through education. The U.S. has historically focused its marketing and educational efforts on deceased donations. ${ }^{263}$ The University of Pittsburgh Medical Center's doctors and administrators assert that education will increase living donations in America. ${ }^{264}$ The provision of the Living Donor Protection Act that requires updating educational materials on the benefits of live organ donation would effectively inform potential living organ donors. Furthermore, well-described public policy positions regarding living donation emanating from this section would narrow the knowledge gap and help increase living donation awareness. ${ }^{265}$

The Department of Labor's response to the Living Donor Protection Act confirming that organ donation can qualify as a serious health condition under the Family and Medical Leave Act is a step in the right direction for organ donation. However, this leave is unpaid unless state law requires the organ donor's employer to provide paid leave. ${ }^{266}$ Furthermore, organ donors often experience financial loss for reasons unrelated to lost wages. ${ }^{267}$ Congress should go even further for living donors by enacting legislation that protects them from lost wages, hospital bills, and other medical expenses. ${ }^{268}$

2. Test Incentives through the Organ Donor Clarification Act.-The Living Donor Protection Act will begin giving living organ donors the protection they need to start increasing organ donation. However, only providing protections may not be enough to encourage potential donors to make a donation. ${ }^{269}$ Providing noncash incentives to encourage organ donation is controversial, but legislatures have no way of knowing whether these types of incentives will increase donation without testing the idea. ${ }^{270}$ The ODCA provides a means to do so by permitting heavily regulated, short-term pilot programs. ${ }^{271}$ The purpose of these pilot programs is to "[measure] the effect of removing disincentives or providing a noncash benefit that may increase the organ pool."272

Before Cartwright introduces the bill to Congress for the third time, the U.S. Representative should include a provision that defines what a noncash benefit is

261. Id.

262. Id.

263. Mabe, supra note 23.

264. Id.

265. Wiseman, supra note 93.

266. Neergaard, supra note 1.

267. Rodrigue et al., supra note 66.

268. See generally Id.

269. Tong et al., supra note 7.

270. Chatterjee et al., supra note 241.

271. Organ Donor Clarification Act of 2018, H.R. 6448, 115th Cong. $§ 3$ (2018).

272. Id. 
for the purposes of the covered pilot programs. For example, the provision could read:

The term 'non-cash benefit' may include tax incentives, retirement fund contributions, loan debt forgiveness, and any other non-cash reward approved by the Secretary of Health and Human Services.

By providing a simple definition for these noncash benefits, the potential abuse and confusion that concerns organizations such as the National Kidney Foundation will be eliminated. ${ }^{273}$

Furthermore, the ODCA will enhance the protections sought through the LDPA. Section 3 of the ODCA sets forth seven types of payments that are not considered valuable consideration under the National Organ Transplant Act. ${ }^{274}$ The purpose of this section is not to allow reimbursements that are not currently allowed under NOTA, but to clarify what can be covered or reimbursed following organ donation. This will clear up any uncertainty that has prevented or delayed reimbursements to living organ donors. ${ }^{275}$

\section{B. State Law}

Several states have already started passing legislation to protect and incentivize living organ donors. ${ }^{276}$ However, the effects of these state laws on increasing organ donation rates are not well-researched. ${ }^{277}$ Additionally, evidence suggests that few people actually know about these policies and are therefore unable to take advantage of them. ${ }^{278}$ Even the most educated and informed donors express a lack of knowledge about eligibility for tax incentives within their state. ${ }^{279}$ Thus, states need to do more to study the effects of their organ donation laws and make residents more aware of the protections and incentives to which they are entitled. In the meantime, remaining states should implement similar laws that provide tax incentives to living donors because these laws cost the states very little, and researchers believe there is no real reason to do away with them. ${ }^{280}$

\section{CONCLUSION}

In order to encourage living organ donation and minimize the growing disparity between the number of patients in need of transplantation and the

273. National Kidney Foundation Statement on The Organ Donation Clarification Act of 2016, supra note 230.

274. Organ Donation Clarification Act of 2018, H.R. 6448, 115th Cong. (2018).

275. Cartwright Announces Legislation to Increase Organ Donation, supra note 113.

276. See Donor Leave Laws and Tax Deductions/Credits for Living Donors, supra note 103; Living Donor Leave Laws: Federal and State by State, supra note 103.

277. See Venkataramani et al., supra note 241.

278. Id.

279. Id.

280. Id.; Chatterjee et al., supra note 241. 
availability of transplantable organs, Congress must enact policies that serve to protect and incentivize potential organ donors. Due to the efforts of U.S. Representatives Nadler, Beutler, and Cartwright, the United States is on its way to protecting living donors and minimizing the gap between the need and supply of organs. To make strides toward improving transplant numbers, federal lawmakers should follow the direction of the several states that have begun providing incentives to living organ donors, such as tax credits and paid time off. Additionally, Congress must ensure that those who are donating and those who are considering donating are protected from insurance discrimination and financial loss. Lastly, the Department of Health and Human Services needs to provide better information about living organ donation to the public to raise awareness and eliminate misperceptions.

This Note has argued that by enacting the Living Donor Protection Act and the Organ Donor Clarification Act, Congress would provide the necessary protections and test possible incentives to end the organ shortage crisis in America. The several studies suggesting that potential donors are unwilling to donate due to the financial burdens, misperceptions about organ donation, and potential inability to obtain life and disability insurance due to their status as a living organ donor support this conclusion. Additionally, this Note has argued that states should continue creating their own protections and incentives for potential organ donors. The task of creating a policy to encourage organ donation may be difficult for lawmakers, but Congress needs to do something to protect the thousands of Americans who will die this year waiting for a transplant. 